\title{
STROPHOMENIDA ОРДОВИКА И СИЛУРА ЭСТОНИИ. III
}

\author{
Род Thaerodonta Wang
}

Характерной группой строфоменидных брахиопод ордовика Северной Эстонии являются плектамбониты (надсемейство Plectambonitacea). В горизонтах эландской серии встречаются представители родов Plectella, Ingria, Ahtiella, Inversella, Leptoptilum, Ukoa (Öpik, 1930, 1932, 1933; Рыымусокс, 1963). В вируской серии установлены роды Inversella, Leptoptilum, Plectambonites, Viruella, Sowerbyella, Leptelloidea, Leptestia, Bilobia, Palaeostrophomena, Tetraodontella, Eoplectodonta (Bekker, 1921, 1922; Öpik, 1930, 1933; Рымусокс, 1959; Jaanusson, 1962), а в харьюской - Sampo, Thaerodonta, Eoplectodonta и Anoptambonites (Öpik, 1933; Jaanusson, 1956; Рыымусокс, 1963).*

В настоящей статье впервые для Эстонии описаны представители рода Thaerodonta, встречающиеся в горизонтах харьюской серии. Оригиналы описанных видов хранятся в Геологическом музее АН Эстонской ССР (Таллин).

Автор благодарен проф. И. Пашкевичюсу (Вильнюс) за литовский сравнительный материал и д-ру В. Яануссону (Стокгольм) за идентификацию одной формы из валунов морены Эйл Мюр с о-ва Готланд.

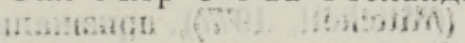

Отряд Strophomenida Öpik, $1934 \ldots-m$ a mats Надсемейство Plectambonitacea Jones, 1928 ,ntanit Aл

Семейство Sowerbyellidae Öpik, 1930

Подсемейство Sowerbyellinae Öpik, $1930 \ldots$ int?

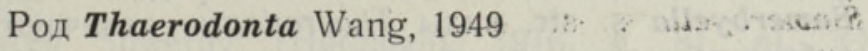

Ти п рода. Thaerodonta aspera Wang, 1949.

Ди агноз. Sowerbyellinae с раковинами от маленьких до средних размеров. На заднем крае спинной створки более или менее развитые зубчики или мелкие бугорки. Зубы небольшие, двураздельные, зубные пластины длинные. Боковые края мускульного поля спинной створки почти не возвышаются над поверхностью створки. Интрамускулярные септы хорошо развиты, срединная септа отсутствует.

Д искуссия. В отношении самостоятельности рода Thaerodonta имеются различные мнения. Одни исследователи, Н. Спьелднес (Spjeldnaes, 1957), А. Вильямс и др. (Williams, и др., 1965), В. Мичел

* Sowerbyella schmidti (Lindström) из пиргуского горизонта Эстонии, изображенный

В. Яануссоном (Jaanusson,-1956), относится к роду Eoplectodonta. 

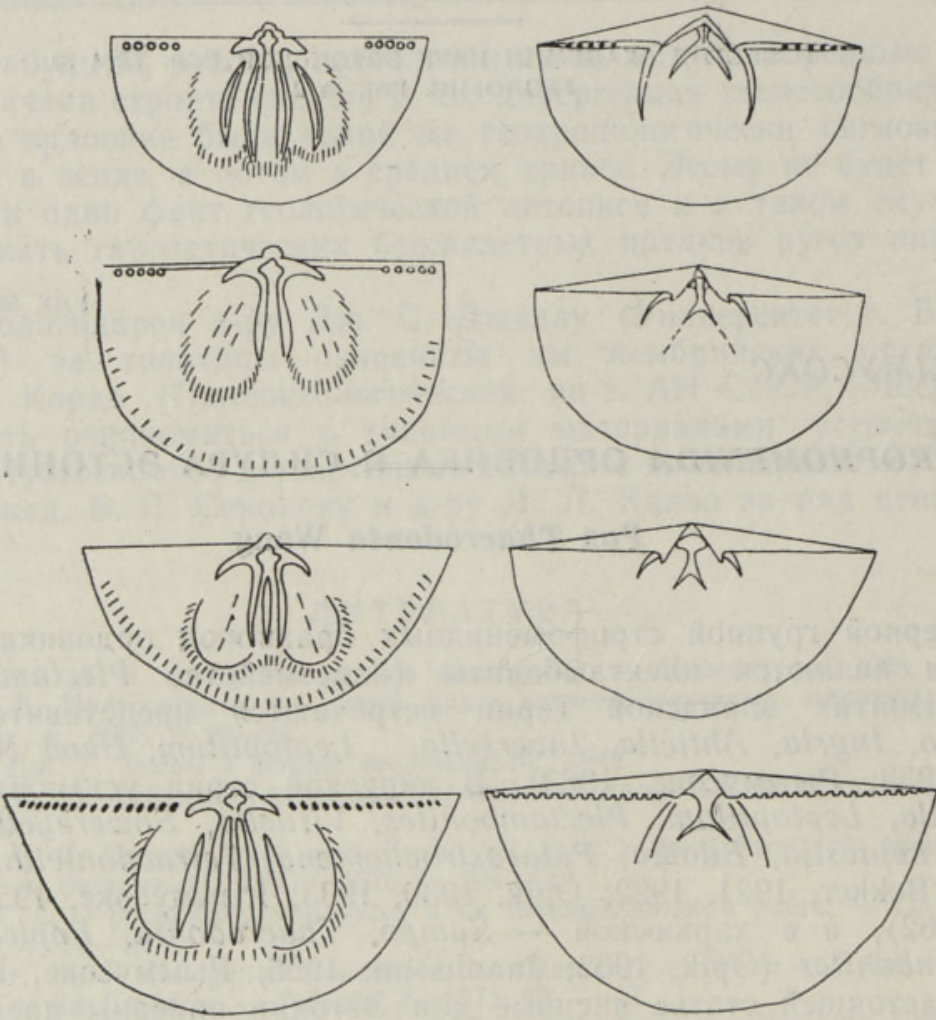

Рис. 1. Сравнение внутреннего строения спинной (левый ряд) и брюшной (правый ряд) створок Thaerodonta, Sowerbyella, Viruella и Eoplectodonta (сверху вниз).

(Mitchell, 1977), признали Thaerodonta младшим синонимом Eoplectodonta, другие - Х. Хоуэ (Howe, 1965, 1972), В. Гавличек (Havliček, 1967), Р. Макомбер (Macomber, 1970), Р. Kокс (Cocks, 1970) и Т. Амсден (Amsden, 1974), наоборот, считают Thaerodonta самостоятельным родом.

Thaerodonta, Sowerbyella, Viruella и Eoplectodonta образуют группу филогенетически довольно близких родов. От представителей рода Sowerbyella s. str. виды Thaerodonta отличаются главным образом зубчатым задним краем, относительно высокими килеобразными интрамускулярными септами и слабо развитым мускульным полем спинной створки. На брюшной створке дельтириальное утолщение и длинные зубные пластины (рис. 1). Правда, некоторые из указанных признаков не являются постоянными или же наблюдаются также у видов Sowerbyella (Ross, 1957; Рыммускс, 1959; Howe, 1965). Это может являться подтверждением точки зрения В. Гавличека (Havliček, 1967, с. 38, рис. 12) и Р. Макомбера (Macomber, 1970), согласно которым предков Thaerodonta следует искать именно среди видов Sowerbyella. От рода Viruella представители Thaerodonta отличаются прежде всего отсутствием срединной септы спинной створки, а также признаками, указанными при сравнении с Sowerbyella (рис. 1). Спинная створка у видов Eoplectodonta имеет ямочки на заднем крае и высокую срединную септу. Кроме того, мускульное поле этой створки обычно ясно огра- 
ничено. На брюшной створке относительно короткие зубные пластины, на заднем крае зубчики. Раковина сама значительно выпуклая. У представителей Thaerodonta все наоборот (рис. 1).

Эстонские виды рода Thaerodonta, описанные автором, несколько отличаются от североамериканских. Вместо настоящих зубчиков у них на заднем крае спинной створки обычно видны только мелкие круглые бугорки (хорошо развитые вблизи замочных углов). Кроме того, брюшная створка у наших видов более выпуклая.

В и ды. K роду Thaerodonta отнесены следующие виды:

Leptaena recedens Sardeson, 1892 (Wang, 1949, p. 20, pl. 11 A, figs 1-3; Howe, 1972, p. 441, pl. 3, fig. 7) - ашгилл, свита Маквокета, Айова, Миннесота, США;

Leptaena saxea Sardeson, 1892 (Wang, 1949, p. 21, pl. 11 B, figs 1-5; Howe, 1972 , p. 441 , pl. 1 , fig. 10 , pl. 2 , figs $9-10$, pl. 3 , figs $1-6-$ ашгилл, свита Маквокета, Айова, Миннесота, США;

Plectambonites rugosus clarksvillensis Foerste, 1912, p. 127, pl. 1, figs $7 a-7 c$, pl. 10, figs $7 a-7 d$ (Wang, 1949, p. 20; Howe, 1972, p. 441 , pl. 1, figs $1-3)$ - ашгилл, ричмонд, Индиана, Кентукки, Огайо, США;

Thaerodonta aspera Wang (1949, p. 20, pl. 11 C, figs $1-5$; Howe, 1972, p. 441, pl. 3, figs 8-14) - ашгилл, свита Маквокета, Айова, США;

Thaerodonta dignata Wang $(1949$, p. 22, pl. 11 D, figs $1-6)$ - ашгилл, свита Маквокета, Айова, США;

Thaerodonta mucronata Howe (1965, p. 648, pl. 81, figs $18-24$ ) - ашгил̈л, группа Монтоя, Техас, США;

Thaerodonta mucronata scabra Howe (1965, p. 648, pl. 82, figs 9-11) ашгилл, группа Монтоя, Техас, США;

Thaerodonta magna Howe (1965, p. 651, pl. 82, figs $1-7 ; 1972$, p. 442 , pl. 1, fig. 11) - ашгилл, группа Монтоя, Техас, США;

Thaerodonta johnsonella Amsden (1974, p. 60, pl. 23, figs $3 a-3 c$, pl. 24, figs $1 a-1 l)$ - ашгилл, свита Лэмон, Миссури, США;

Thaerodonta saunjaensis sp. n.;

Thaerodonta moelsi sp. n.;

Thaerodonta convexa sp. n.;

Thaerodonta nubila sp. $\mathrm{n}$.

K рассматриваемому роду относятся еще следующие более или менее известные формы:

Leptaena transversalis Dalman (Wiman, 1902, S. 179) - из ледниковых валунов известняка поркуниского горизонта - ашгилл, Эйл Мюр, о-в Готланд;

Plectambonites sericea Sowerby (Holtedahl, 1916, p. 81, pl. XIV, figs $1-3$ ) - ашгилл, слои 5а, Рингерике, Мёса, Норвегия;

Plectambonites rugosus manitouliensis Foerste (1924, p. 113, pl. XIV, figs $4 a-4 d)$ - ашгилл, слои Мифорд, о-в Манитулин, Онтарио, Канада;

Sowerbyella sladensis Jones (1928, p. 421, pl. XXI, figs 14-17) ашгилл, слои Слейд и Ддолхир, Уэльс, Англия;

Sowerbyella sladensis Jones (Алихова и др., 1954, с. 28, табл. XV, фиг. $1-6)$ - верхний карадок, оандуский и раквереский горизонты, Литовская ССР (см. также Р. Мянниль, 1966, с. 63 и 73, разрезы скв. Укмерге и Крякянава);

Thaerodonta cf. recedens (Sardeson) (Ross, 1957, p. 481, pl. 40, figs 26-28) - ашгилл, свита Ред Ривер, Монтана, США;

Thaerodonta cf. recedens (Sardeson) (Howe, 1965, p. 649, pl. 81, figs $13-17)$ - ашгилл, группа Монтоя, Техас, США; 


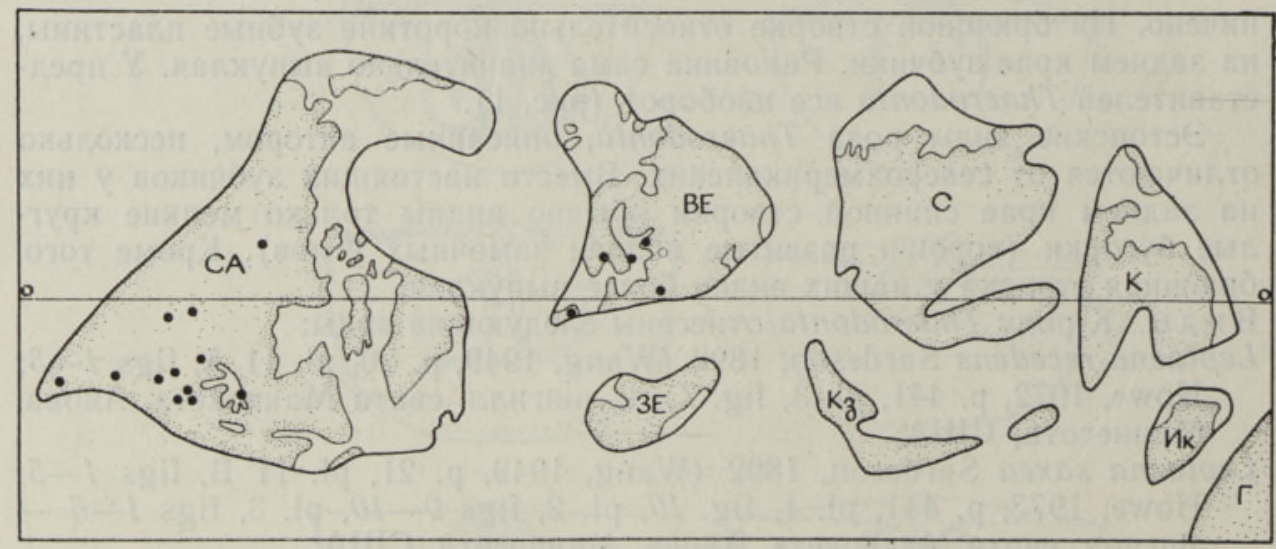

Рис. 2. Распространение перечисленных видов Thaerodonta (см. с. 63) в карадокском (белый круг) и ашгиллском (черный круг) веках. Реконструкция континентов по А. М. Городницкому и др. (1978). Континенты и микроконтиненты: СА - СевероАмериканский, ВЕ - Восточно-Европейский, ЗЕ - Западно-Европейский, С - Сибирский, Кз - Казахстанский, К - Китайский, Ик - Индокитайский, Г - Гондванский, Жирной линией обозначены контуры континентов, тонкой линией - континенты в пределах современной суши. $0-0-$ Экватор.

Thaerodonta aff. clarksvillensis (Foerste) (Macomber, 1970, p. 439, pl. 78, figs $1-15$ ) - ашгилл, верхняя часть свиты Бигорн, Вайоминг, США; Thaerodonta cf. recedens (Sardeson) (Norford, Macqueen, 1975, pl. 9, figs $11-14)$ - ашгилл, основание свиты Моунт Кайндел, Макензи, Канада;

Thaerodonta sp. (Sheehan, 1975, p. 207, pl. 1, figs 27-30) - ашгилл, основание свиты Солис, Чиуауа, Мексика;

Thaerodonta sp. (определен автором в коллекции П. Д. Цегельнюка) ашгилл, субочкие слои молодовского горизонта, Подолия, Украинская ССР.

Р аспространение. Род Thaerodonta установлен по приведенным данным в Северной Америке и Европе (рис. 2). Наиболее древним известным автору представителем рода является еще неописанная форма из верхнего карадока (оандуский $\left(D_{\mathrm{III}}\right)$ и раквереский $(E)$ горизонты) Литовской ССР. Если это так, то центром радиации Thaerodonta следует считать Прибалтику, где вероятные предки его (Sowerbyella) появились еще в лланвирнском веке (Рыымусокс, 1959). Следующей по возрасту формой является $T$. saunjaensis sp. п. из набалаского горизонта (сауньяская пачка воорэской свиты), т. е. низов ашгилла Северной Эстонии. Все другие перечисленные выше виды происходят по большей части из верхнеашгиллских отложений и распространяются главным образом в Северной Америке.

\section{ТАБЛИЦА I}

Фиг. 1-5. Thaerodonta saunjaensis sp. n. 1 - внутреннее строение брюшной створки $\mathrm{Br} 1228$, Мяэметса, $\mathrm{F}_{\mathrm{I}} \mathrm{aV} \mathrm{V}^{\prime} \mathrm{S}$, колл. Э. Мэлса, $\times 5,2 ; 2$ - внутреннее строение спинной створки $\mathrm{Br} 1209$, Тырма, $\mathrm{F}_{\mathrm{I}} \mathrm{V}^{\prime} \mathrm{S}$, колл. эксп., $\times 4 ; 3$ - голотип $\mathrm{Br} 1211$, Мяэметса, $\mathrm{F}_{\mathrm{IaV}} \mathrm{S}$, колл. P. Мянниля; 4 - спинная створка $\mathrm{Br} 1207$, Мынусте, $\mathrm{F}_{1 \mathrm{aV}} \mathrm{S}$, колл. автора и Д. Кальо, $\times 5 ; 5$ - внутреннее строение спинной створки $\mathrm{Br} 1210$, Тырма, $\mathrm{F}_{\mathrm{IaV}} \mathrm{S}$, колл. автора, $\times 5$. Фиг, 6-11. Thaerodonta moelsi sp. n. 6 - голотип $\mathrm{Br} 1199$, целая раковина, Кыргессааре, FI спинной створки $\mathrm{Br} 1200$, Нийби, $\mathrm{F}_{\mathrm{IcM}}$, колл. автора и Д. Қальо, $\times 3,5 ; 8-11-$ целая раковина $\mathrm{Br} 1203, \mathrm{~K}$ ыргессааре, FI $\mathrm{bK}$, колл. автора, ×3,5. 
ТАБЛИЦА I

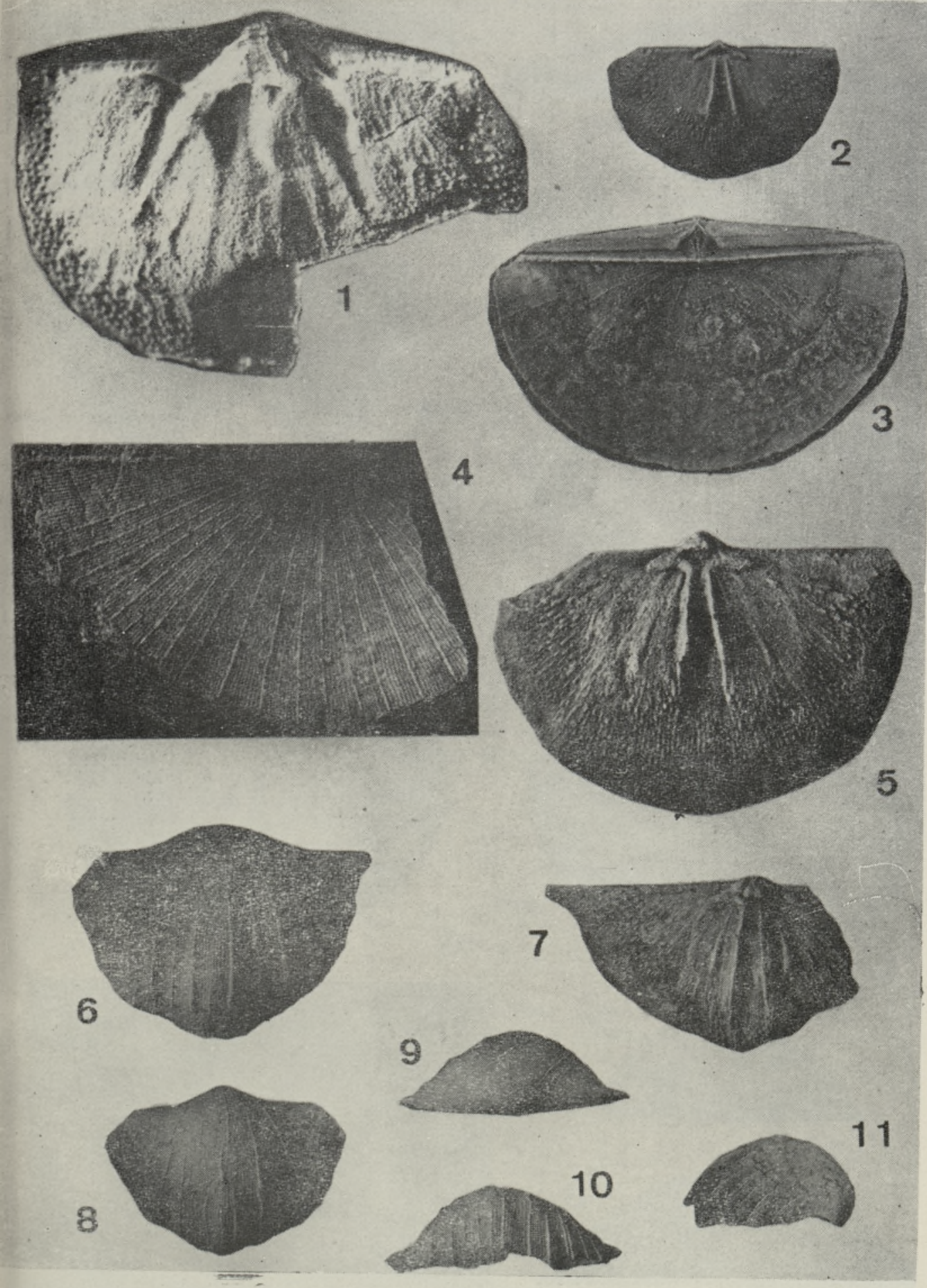




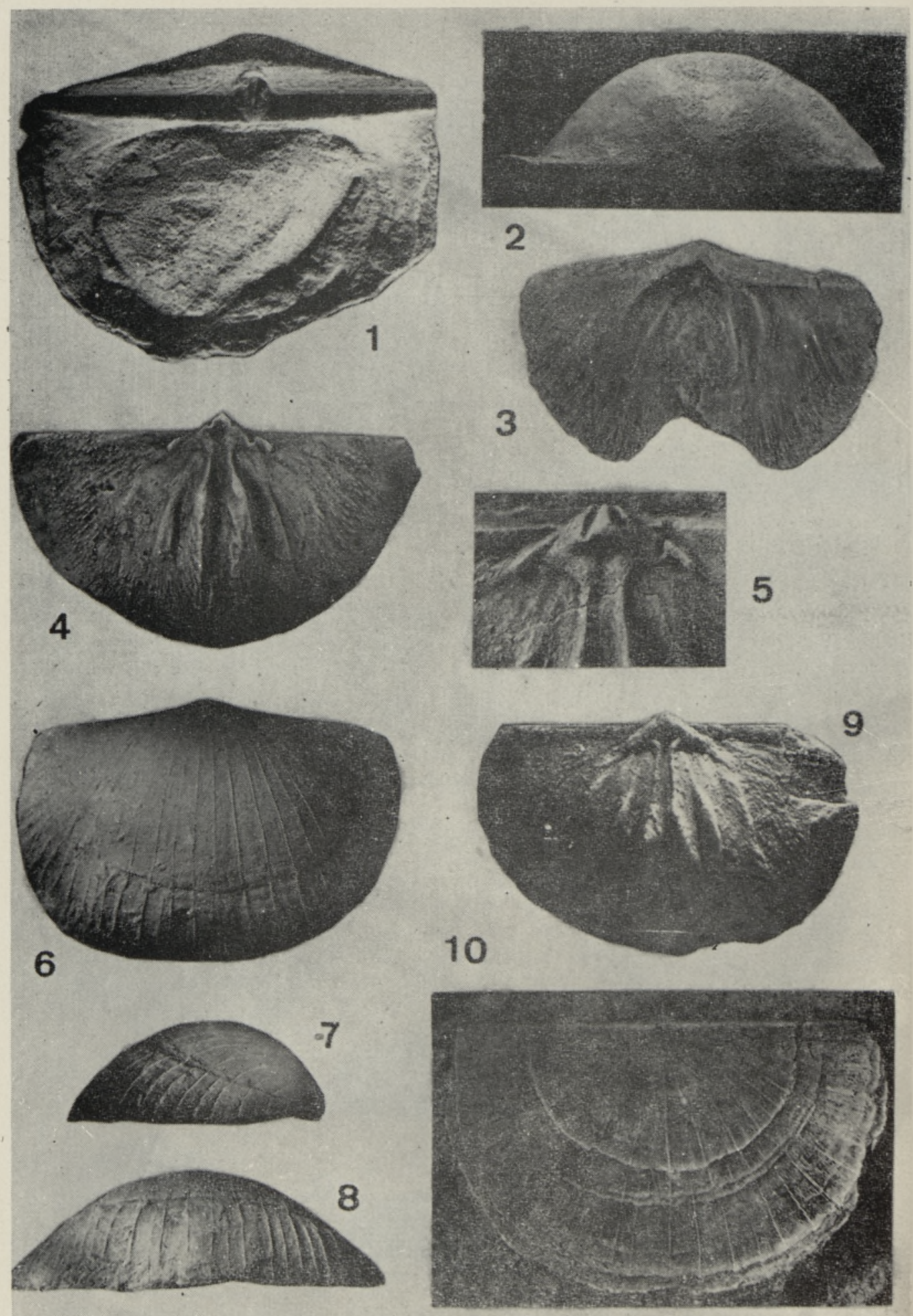


Thaerodonta saunjaensis sp. n.*

Табл. I, фиг. $1-5$

Гол оти п. Брюшная створка (Br 1211) (табл. I, фиг. 3), набалаский горизонт, сауньяская пачка воорэской свиты $\left(\mathrm{F}_{\mathrm{I}} \mathrm{aV} \mathrm{S}\right)$, Мяэметса, колл. Р. Мянниля.

Д и а г о з. Thaerodonta с небольшой полуовальной плоской раковиной. Внутренние края отпечатков аддукторов спинной створки умеренно килеобразно повышены, интрамускулярные септы слабо развиты.

О писание. Брюшная створка слабо выпуклая, дельтидиальные пластинки очень узкие.

Поверхность раковины покрыта тонкими, округленными, тесно друг к другу прилегающими, разнородными по толщине радиальными ребрышками. Каждые 6-12 ребрышек на переднем крае толще других. На 1 мм переднего края приходится 8-9 ребрышек.

Внутри брюшной створки большие двураздельные зубы, поддерживаемые длинными, достигающими почти центра створки, зубными пластинами. Срединная септа толстая, короткая и повышена, со слабо развитыми ветвями.

Внутри спинной створки небольшой трехлопастный кардинальный отросток, средняя лопасть которого отделена от соседних лопастей очень узкими неглубокими бороздами. Приямочные пластины очень короткие, относительно толстые и с небольшими острыми окончаниями. Замочная впадина широкая, но низкая. Зубные ямы узкие, неглубокие. Отпечатки аддукторов слабо выражены, полуовального очертания и окаймлены впереди немногими удлиненными радиальными бугорками. Внутренние края отпечатков умеренно килеобразно повышены. Интрамускулярные септы представлены слабо развитыми округленными диагональными валиками. Вблизи заднего края створки иногда наблюдается ряд мелких округленных бугорков.

Размеры (мм) (см. также рис. 3):

$\begin{array}{llcccc}\text { Длина } & \begin{array}{c}\text { Длина } \\ \text { спинной } \\ \text { створки }\end{array} & \begin{array}{c}\text { Ширина } \\ \text { заднего } \\ \text { края }\end{array} & \text { Толщина } \\ \mathrm{Br} & 1211 \text { (голотип) } & 10,0 & 8,8 & 16,0 & 3,7 \\ \mathrm{Br} & 1206 & 8,7 & ? & 14,1 & 2,8 \\ \mathrm{Br} & 1213 & 6,1 & 5,5 & 10,6 & 2,1\end{array}$

С р а внени е. Раковины описываемого вида очень сходны с раковинами других видов по облику, но отличаются некоторыми признаками внутреннего строения, в частности спинной створки, например, слабо

* Название дается по распространению в Эстонии в сауньяской пачке.

\section{ТАБЛИЦА II}

Фиг. 1-5. Thaerodonta convexa sp. п. $1-2-$ голотип $\mathrm{Br} 1561$, Паопа, $\mathrm{F}_{\mathrm{I}} \mathrm{bK}, \times 3$; 3 - внутреннее строение брюшной створки $\mathrm{Br} 1215$, Кыргессааре, $\mathrm{F}_{\mathrm{I}} \mathrm{bK}$, колл. А. Эпика, $\times 3 ; 4-5-$ внутреннее строение спинной створки $\mathrm{Br} 1106$, Кюти, $\mathrm{F}_{\mathrm{I}} \mathrm{bK}$, колл. Ф. Шмидта; $4-\times 3,2 ; 5-\times 6$. Фиг. $6-10$. Thaerodonta nubila sp. n. $6-8-$ голотип $\mathrm{Br} 1105$, Хаапсалуский Хольм, F $\mathrm{ICA}$, колл. В. Реймера, $\times 3,3 ; 9-$ внутреннее строение спинной створки $\mathrm{Br} 1554$, Ууэмыйза, $\mathrm{F}_{\mathrm{I}} \mathrm{A}, \times 3,3 ; 10-$ спинная створка $\mathrm{Br} 1107$, Ууэмыйза, $\mathrm{F}_{\mathrm{I}} \mathrm{AA}, \times 4$. 


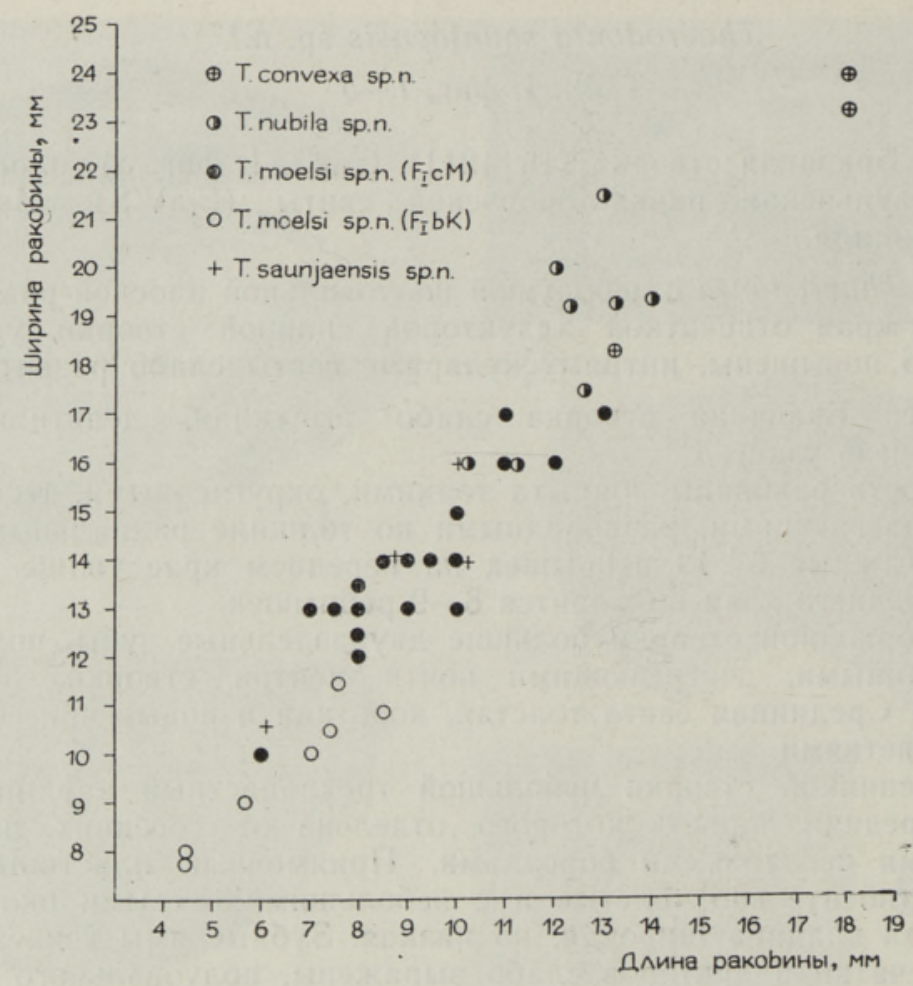

Рис. 3. Распределение целых экземпляров описанных видов по отношению ширины и длины створки. Экземпляры T. moelsi sp. n. из кыргессаареской $\left(\mathrm{F}_{\mathrm{I}} \mathrm{bK}\right)$ и моэской (FIcM) свит обозначены различными условными знаками.

развитыми интрамускулярными септами и хорошо развитыми мелкими бугорками на заднем крае. По этим же признакам T. saunjaensis sp. n. сближается к роду Sowerbyella, что, несомненно, указывает на близкую филогенетическую связь. T. saunjaensis sp. n. наиболее близок к T. nubila sp. n., но отличается от него размерами, более плоской раковиной, более грубой скульптурой и слабее развитым мускульным полем спинной створки.

Р аспростр анени е. Северная Эстония. Набалаский горизонт, сауньяская пачка воорэской свиты $\left(\mathrm{F}_{\mathrm{IaV}} \mathrm{S}\right)$ - Одулема, 10 экз.; Мынусте, 4 экз.; Кохату, 1 экз.; Мяэметса, 3 экз.; канава у д. Ору, 1 экз.; Тырма, 6 экз.

Thaerodonta moelsi sp. n.*

Табл. I, фиг. 6-11

Голоти п. Целый экземпляр ( $\mathrm{Br} 1199)$ (табл. I, фиг. 6), вормсиский горизонт, кыргессаареская свита $\left(\mathrm{F}_{\mathrm{I}} \mathrm{bK}\right)$, каменоломня Кыргессааре, колл. Э. Мэлса.

Ди агно з. Thaerodonta с небольшой треугольной относительно выпуклой раковиной.

* Название дается в память доцента кафедры геологии ТГУ Э. Мэлса. 
О п и с а н ие. Брюшная створка значительно выпуклая. В среднем секторе створки у переднего края едва заметный продольный выступ. Имеются узкие дельтидиальные пластины. Спинная створка глубоко вогнута.

Поверхность раковины покрыта разнородными по толщине ребрышками. От макушки брюшной створки начинаются три основных ребрышка, в промежутках между которыми (в задней трети створки) появляются дополнительные более грубые ребрышки. У переднего края створки каждые 8-10 ребрышек толще других. На 1 мм переднего края приходится 7-9 ребрышек. На спинной створке основные ребрышки развиты менее отчетливо. При хорошей сохранности на ребрышках наблюдается очень тонкая поперечная струйчатость.

Внутри брюшной створки (по единичному плохо сохраненному экземпляру $\mathrm{Br} 1202)$ небольшие зубы, поддерживаемые слабо развитыми зубными пластинами. Внутри спинной створки имеется относительно массивный трехлопастный кардинальный отросток, средняя лопасть которого отделена от соседних глубокими и относительно широкими бороздами. Зубные ямы продолговатые. Отпечатки аддукторов также продолговатые. Они почти не возвышаются над поверхностью створки. Внутренние края отпечатков аддукторов незначительно килеобразно повышены. Интрамускулярные септы тонкие, утолщаясь к переди. Вблизи замочных углов наблюдаются некоторые относительно крупные округленные бугорки.

Размеры (мм) (см. также рис. 3):

$\begin{array}{lccc}\text { Длина } & \begin{array}{c}\text { Длина } \\ \text { спинной } \\ \text { створки }\end{array} & \begin{array}{c}\text { Ширина } \\ \text { заднего } \\ \text { края }\end{array} & \text { Толщнна } \\ 9 & - & 12,3 & 4,4 \\ 7,4 & 5,2 & ? & 4 \\ 5,7 & 4,4 & 9 & 2,5\end{array}$

$\begin{array}{lllccl}\mathrm{Br} & 1199 \text { (голотип) } & 9 & - & 12,3 & 4,4 \\ \mathrm{Br} & 1203 & 7,4 & 5,2 & ? & 4 \\ \mathrm{Br} & 1204 & 5,7 & 4,4 & 9 & 2,5\end{array}$

С р а внение. Описываемый вид отличается от других эстонских видов главным образом треугольной раковиной меньших размеров. Внутреннее строение раковины наиболее сходно с $T$. convexa sp. n., но спинная створка последнего более выпуклая, а интрамускулярные септы и килеобразные внутренние края мускульных отпечатков более высокие.

Р а сп ростр ан ени е. Северная Эстония. Вормсиский горизонт, кыргессаареская свита $\left(\mathrm{F}_{\mathrm{I}} \mathrm{bK}\right)$ - о-в Хийумаa, Кыргессааре, 23 экз., Паопа, 1 экз., Палукюла, 1 экз.; о-в Вормси, берег у Саксби (северный), 2 экз., Боррби, 2 экз.; Мынусте, 3 экз.; Кохила (уступ), 1 экз.; р. Ката 1 экз.; Кюти -1 экз.

Пиргуский горизонт, моэская свита $\left(\mathrm{F}_{\mathrm{I}} \mathrm{cM}\right)$ - о-в Вормси, Саксби (старая каменоломня), 50 экз., Кяррслят (юго-западная каменоломня), 1 экз., берег у Саксби (южный), 1 экз.; Нийби, 3 экз.; Капри, 1 экз.; Вяльятагузе, 1 экз,; Салутагузе, 1 экз.

Thaerodonta convexa sp. $\mathrm{n}$.

Табл. ІІ, фиг. $1-5$

Голотип. Целый экземпляр ( $\mathrm{Br} 1561)$ (табл. II, фиг. 1-2), вормсиский горизонт, кыргессаареская свита $\left(\mathrm{F}_{\mathrm{I}} \mathrm{bK}\right)$, Паопа.

Д и агноз. Thaerodonta с большой, полукруглой, очень выпуклой раковиной. 
О писани е. Раковина для эстонских видов рода крупная, почти полу: круглого очертания. Брюшная створка значительно и равномерно выпуклая. Дельтидиальные пластинки узкие.

Скульптура раковины состоит из очень тонких округленных, разнородных ребрышек. В относительно широких промежутках более грубых ребрышек приблизительно 10 мелких. На 1 мм переднего края приходится около $10-12$ ребрышек.

Внутри брюшной створки значительно пониженное мускульное поле. Зубы небольшие. Зубные пластины хорошо развиты, их передние концы доходят до центральной части створки. Срединная септа короткая и толстая, ее ветви доходят до середины створки. Внутренная поверхность спинной створки в среднем секторе более или менее выпуклая, причем -задний склон створки значительно круче переднего. Замочная впадина узкая и глубокая. Зубные ямы узкие, относительно глубоқие и продолговатого очертания. Отпечатки аддукторов большие, полуовального очертания, очень слабо ограничены. Внутренние края отнечатков аддукторов сильно килеобразно повышены, образуя тонкие высокие пластинки. Интрамускулярные септы (развитые в передней части отпечатков аддукторов) относительно высокие. Высота этих седт доходит до полювины высоты внутренных краев отпечатков мускулов, У замочных углов наблюдается ряд мелких округленных бугорков.

На более поздних стадиях онтогенеза спинная створка становится более выпуклой, причем мускульное поле может иметь почти вертикальное положение (кардинальный отросток в этом случае расположен горизонтально - т. е. на одном уровне с передним и задним краями створки).

Размеры (мм) (см. также рис. 3):

$\begin{array}{lccc} & \text { Длина } & \begin{array}{c}\text { Ширина заднего } \\ \text { края }\end{array} & \text { Толщина } \\ \operatorname{Br} 1561 \text { (голотип) } & 18 & 23,2 & 8 \\ \operatorname{Br} 1562 & 18 & 24 & 6,6 \\ \operatorname{Br} 1563 & 13,2 & 18,3 & 5\end{array}$

C р а в нение. $T$. convexa sp. n. отличается от других эстонских видов рода крупной значительно выпуклой раковиной.

Р асп ростр анен и е. Северная Эстония. Вормсиский горизонт, кыргессаареская свита (FI $\mathrm{FK})$ - о-в Хийумаа, Кыргессааре, 6 экз., Паопа, 9 экз., Кярдла, 1 экз.; о-в Вормси, берег у Саксби (северный), 6 экз., Боррби, 2 экз.; Ликгольм (Сааремыйза), 2 экз.; Ныммкюла, 6 экз.; Мынусте, 2 экз.; Кохила, 1 экз.; Лехтсе, 2 экз.; Тапа, 2 экз.; Кюти, 11 экз.; Имасту, 1 экз.

Пиргуский горизонт, моэская свита (FIcM) - о-в Вормси, Саксби (старая каменоломня), 1 экз., Саксби (новая каменоломня), 2 экз.; о-в Хийумаа, Палукюла, 2 экз.; Нийби, 3 экз.; Салутагузе, 1 экз.

\section{Thaerodonta nubila sp. $\mathrm{n}$.}

Табл. II, фиг. 6-10

Голотип. Целый экземпляр (Br 1105) изображен на табл. II, фиг. $6-8$, пиргуский горизонт, адилаская свита, (FIcA), Хаапсалуский Хольм, колл. В. Реймера.

Ди агно 3. Thaerodonta с большой полуовальной, вытянутой в ширину 
раковиной. Интрамускулярные септы спинной створки длинные и относительно высокие.

Описание. Брюшная створка умеренно выпуклая. Дельтидий апикальный, едва заметный.

Поверхность раковины покрыта относительно тонкими ребрышками. На переднем крае раковины каждые 8-11 ребрышек толще других. На 1 мм переднего края приходится около 10 ребрышек.

Внутренная поверхность спинной створки в среднем секторе более или менее выпуклая, причем задний склон круче переднего. Замочная впадина узкая и глубокая. Зубные ямы глубокие, узкие, продолговатого очертания. Отпечатки аддукторов большие, полуовального очертания и очень слабо развиты. Их внутренние края сильно килеобразно повышены, образуя тонкие пластинки. К переди они заметно расходятся. Интрамускулярные септы узкие, длинные и развиты в передней части мускульного поля. У замочных углов вблизи заднего края наблюдается ряд небольших округленных бугорков.

Размеры (мм) (см. также рис. 3):

\begin{tabular}{|c|c|c|c|c|}
\hline & Длина & $\begin{array}{l}\text { Длина } \\
\text { спинной } \\
\text { створки }\end{array}$ & $\begin{array}{c}\text { Ширина } \\
\text { заднего } \\
\text { края }\end{array}$ & Толщина \\
\hline $\mathrm{Br} 1105$ (голотин) & 13,2 & 11,4 & 19,3 & 7 \\
\hline Br 1108 & 14 & & 19,4 & 6,2 \\
\hline $\mathrm{Br} 1109$ & 13 & 10,8 & 21,5 & 5,2 \\
\hline $\mathrm{Br} 1205$ & 12 & 9,8 & 20 & 5 \\
\hline
\end{tabular}

С ра внени е. T. nubila отличается от других эстонских видов в первую очередь полуовальной вытянутой в ширину раковиной. Она более плоская, чем у T. moelsi sp. п. и T. convexa sp. n. Скульптура раковины нежная.

Р аспространени е. Северная Эстония. Пиргуский горизонт, адилаская свита $\left(\mathrm{F}_{\mathrm{I}} \mathrm{A}\right)$ - о-в Хийумаа, у бывшей корчмы Палукюла (колл. Ф. Шмидта), 7 экз.; о-в Вохилайд, 11 экз.; о-в Вормси, Хусгольм, 6 экз.; Хаапсалуский Хольм, массово; Ууэмыйза, 19 экз.; Пийрсалу, 5 экз;; Варди (валуны), 4 экз.; Тянавотса, 3 экз.; Адила, 1 экз.; русло р. Пиргу у бывшего имения, 10 экз.; канава у перекрестка дорог Амбла-Коэру, 4 экз.; буровая скв. Лихувески (гл. 99,54 м), 1 экз. Рёаская пачка эринаской свиты $\left(\mathrm{F}_{\mathrm{I}} \overline{\mathrm{A}}^{\prime} \mathrm{R}\right)$ - о-в Вохилайд (колл. Ф. Шмидта), 10 экз.; Рёа, 3 экз.; буровая скв. Азукюла (гл. 40,12-40,15 м), 7 экз.; буровая скв. Мартна (гл. 52,02-52,09 м), 1 экз.; буровая скв. Виртсу (гл. 131,00 м, 3 экз.; гл. 131,65 м, 1 экз.).

Поркуниский горизонт, вохилайдская пачка эринаской свиты $\left(\mathrm{F}_{\mathrm{II}} \mathrm{A}^{\prime} \mathrm{V}\right)-$ Рёа-Яагупи, 13 экз.

\section{Л И Т Р А Т Р А}

Алихова Т. Н., Бал ашов а Е. А., Балашов Э. Г. Полевой атлас характерных комплексов фауны отложений ордовика и готландия южной части Литовской ССР. М., 1954.

Го родницкий А. М., Зоненш айн Л. П., Ми рлин Е. Г. Реконструкции положения материков в фанерозое. М., 1978.

М янниль Р. М. История развития Балтийского бассейна в ордовике. Таллин, 1966.

Р ы ы у сокс А. Strophomenoidea ордовика и силура Эстонии. I. Род Sowerbyella Jones. - Уч. зап. ТГУ, вып. 75, Тарту, 1959, $11-50$.

Р ы м у сокс А. Strophomenoidea ордовика и силура Эстонии. II. Новые роды и виды из харьюской серии. - Изв. АН ЭССР, сер. биол., 1963, 12, 231-241. 
A m s de n, T. W. Late Ordovician and Early Silurian articulate brachiopods from Oklahoma, Southwestern Illinois, and Eastern Missouri. - Oklah. Geol. Surv. Bull. $1974,119$.

B ekker, H. The Kuckers stage of the Ordovician rocks of NE Estonia. - Acta Univ. Tartu, A 2, 1921.

B e k ker, H. A new brachiopod (Leptestia) from the Kuckers stage in Estonia. - Geol. Mag., 1922, 59, 361-365.

Cocks, L. R. M. Silurian brachiopods of the superfamily Plectambonitacea. - Bull. Brit. Mus. Nat. Hist. (Geol.), London, 1970, 19, 139-203, pl. 1-17.

Foerste, A. F. Strophomena and other fossils from Cincinnatian and Mohawkian horizons, chiefly in Ohio, Indiana and Kentucky. - Denison Univ., Bull. Sci. Lab., 1912, 17, 17-174, pl. 1-11.

Foerste, A. F. Upper Ordovician faunas of Ontario and Quebec. - Canad. Geol. Surv., Mem., 1924, 138, pl. 10-15.

Havliček, V. Brachiopoda of suborder Strophomenidina in Czechoslovakia. Rozpravy Ústředn. ústavu geologického. Svazek 33. Praha, 1967.

Holtedahl, O. The Strophomenidae of the Kristiania region. - Vidensk. Selsk. Skrifter. I. Mat.-Naturvidensk. KI., 1916, 12.

How e, H. J. Plectambonitacea, Strophomenacea and Atrypacea from the Montoya group (Ordovician) of Trans-Pecos Texas. - J. Paleont., 1965, 39, 647-656.

Howe, H. J. Morphology of the brachiopod genus Thaerodonta. - J. Paleont., 1972, $46,440-446$.

$\mathrm{J}$ a a nus s o n, V. Untersuchungen über den oberordovizischen Lyckholm-Stufenkomplex in Estland. - Publ. Pal. Inst. Univ. Uppsala, 1956, 12, 369-400, Taf. I.

$\mathrm{J}$ a a nus s o n, V. Two Plectambonitacean brachiopods from the Dalby limestone (Ordov.) of Sweden. - Publ. Pal. Inst. Univ. Uppsala, 1962, 40, 1-8, pl. I.

J o nes, O. T. Plectambonites and some allied genera. - Mem. Geol. Surv. U. K., London, (Paleont.), 1928, 1, part 5, 367-527.

M a c om b e r, R. W. Articulate brachiopods from the Upper Bighorn formation (Late Ordovician) of Wyoming. - J. Paleont., 1970, 44, 416-450.

Mitchell, W. I. The Ordovician Brachiopoda from Pomeroy. Co. Tyrone. Paleontographical Soc., London, 1977.

Norford, B. S., Ma c que en, R. W. Lower Paleozoic Franklin Mountain and Mount Kindle formations, district of Mackenzie: their type sections and regional development. - Geol. Surv. Papers, 74-34, Ottawa, 1975.

Ross, R. J. (Jr.). Ordovician fossils from Wells in the Williston Basin, eastern Montana. U. S. Geol. Surv., Bull. 1021-M, 1957, 438-506, pl. 37-43.

$\mathrm{S}$ he eh a n, P. M. Upper Ordovician and Silurian brachiopods from the Solis limestone, Chihuahua, Mexico. - J. Paleont., 1975, 49, 200-211.

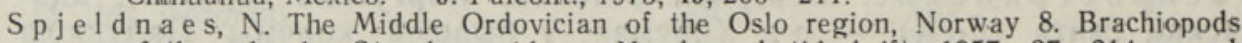
of the suborder Strophomenida. - Norsk geol. tidsskrift, 1957, 37, 214 p., pl. $1-14$.

W a n g, Y. Maquoketa brachiopoda of Iowa. - Geol. Soc. Amer., Mem. 1949, 42.

Williams, A. et al. Treatise on invertebrate paleontology. Part H. Brachiopoda. Geol. Soc. Amer. Univ., 1965, 1-2.

W i m a n, C. Uber die Borkholmer Schicht im Mittelbaltischen Silurgebiet. - Bull. Geol. Inst. Uppsala, 1902, vol. V, part 2, N 10, 149-222.

Op ik, A. Brachiopoda Protremata der estländischen ordovizischen Kukruse-Stufe. Acta Univ. Tartu, A 17, 1930.

O p i k, A. Uber Plectellinen. - Acta Univ. Tartu, A 23, 1932.

O p i k, A. Ober Plectamboniten. - Acta Univ. Tartu, A 24, 1933.

Тартуский государственный университет

Поступила в редакцию $31 / \mathrm{X} 1980$ 


\section{A. ROOMUSOKS}

\section{EESTI ORDOVIITSIUMI JA SILURI STROPHOMENIDA. III}

\section{Perekond Thaerodonta Wang}

Brahhiopoodide perekonda Thaerodonta käsitatakse käesolevas artiklis iseseisvana; kons perekondadega Sowerbyella, Viruella ja Eoplectodonta moodustab ta mitmete ühiste joontega plektamboniitide grupi. Thaerodonta on levinud Euroopas ja Põhja-Ameerikas. Vanimad vormid esinevad Leedus ja Eestis oandu, rakvere ning nabala lademes (UlemCaradoc ja Alam-Ashgill). See viitab võimalusele, et Thaerodonta tekkekeskus oli Baltikum. Thaerodonta eellasi tuleb otsida perekonnast Sowerbyella (s. str.). Enamik tuntud Thaerodonta liike esineb Pōhja-Ameerikas Ashgilli ladejärgu ülemises osas.

Artiklis on esmakordselt kirjeldatud nelja Eesti ülemordoviitsiumi (Harju seeria) kuuluvat Thaerodonta liiki: T. saunjaensis sp. n., T. moelsi sp. n., T. convexa sp. n. ja T. nubila sp. $\mathrm{n}$,

\section{A. ROOMUSOKS}

\section{ORDOVICIAN AND SILURIAN STROPHOMENIDA OF ESTONIA. III}

\section{Genus Thaerodonta Wang}

The present article describes, for the first time from Estonia, four species of brachiopod Thaerodonta (T. saunjaensis sp. n., T. moelsi sp. n., T. convexa sp. n., T. nubila $\mathrm{sp}$. n.) from the Upper Ordovician of Estonia (Harjuan Series). Contrary to the viewpoint of many authors, Thaerodonta is considered an independent plectambonitacean genus which is still very closely related to the genera Sowerbyella, Viruella and Eoplectodonta. Thaerodonta is distributed in Europe and North America. The oldest forms occur in the Lithuanian SSR and in the Estonian SSR, in the Oandu, Rakvere and Nabala Stages (Upper Caradoc and Lower Ashgill). This refers to the possibility that the centre of radiation of Thaerodonta has been in the Baltic countries. Its predecessors must have been the forms of Sowerbyella (s. str.).

The described species of Thaerodonta occurring in Estonia somewhat differ from those of North America. Instead of real denticles they have only tubercles on the brachial valve hinge line. Besides, the shells of the Estonian species are more convex. The majority of the known species of Thaerodonta occur in the Upper Ashgill of North America.

\section{Thaerodonta saunjaensis sp. $\mathrm{n}$.}

Small Thaerodonta with semioval flat shell. Dorsal inner side septa moderately high, outer side septa weakly developed. Northern Estonia. Lower Ashgill. Nabala Stage, Saunja Member of the Voore Formation $\left(\mathrm{F}_{1} \mathrm{aV}\right.$ 'S $)$.

\section{Thaerodonta moelsi sp. n.}

Small Thaerodonta with triangular, relatively convex shell. Northern Estonia. Lower Ashgill. Vormsi Stage, Körgessaare Formation $\left(\mathrm{F}_{\mathrm{I}} \mathrm{bK}\right)$ and Pirgu Stage, Moe Formation $\left(\mathrm{F}_{\mathrm{I}} \mathrm{cM}\right)$.

\section{Thaerodonta convexa sp. $\mathrm{n}$.}

Large Thaerodonta with semicircular, very convex shell. Northern Estonia. Lower Ashgill. Vormsi Stage, Körgessaare Formation $\left(\mathrm{F}_{\mathrm{I}} \mathrm{bK}\right)$ and Pirgu Stage, Moe Formation $\left(\mathrm{F}_{\mathrm{I}} \mathrm{cM}\right)$.

\section{Thaerodonta nubila sp. $\mathrm{n}$.}

Large Thaerodonta with semioval relatively wide shell. Dorsal outer side septa long and relatively high. Northern Estonia. Upper Ashgill. Pirgu Stage, Adila Formation $\left(\mathrm{F}_{\mathrm{I}} \mathrm{cA}\right)$ and Röa Member of the Arina Formation $\left(F_{I} \subset A^{\prime} R\right)$. Porkuni Stage, Vohilaid Member of the Arina Formation $\left(\mathrm{F}_{\mathrm{II}} \AA^{\prime} \mathrm{V}\right)$. 